\title{
La Camarería Mayor en la corte de Fernando VII: Un espacio nobilia- rio de poder informal y capital simbólico*
}

\author{
Antonio Manuel Moral Roncal ${ }^{1}$ \\ Universidad de Alcalá \\ antonio.moral@uah.es
}

RESUMEN: El objetivo de este artículo es valorar si una de las secciones de la Real Casa fue un espacio de poder informal y acumulación de capital simbólico para las mujeres de la nobleza española en el reinado de Fernando VII. Se trata de un periodo intermedio entre la sociedad cortesana del siglo XVIII y las transformaciones que el liberalismo provocó en la misma, a partir de 1833. El autor pretende comenzar a rellenar ese vacio, necesario para comprender la evolución del entorno femenino de la corte, basándose en la documentación existente en el Archivo General del Palacio Real de Madrid. Resulta también sustancial conocer el papel que el monarca atribuyó al personal femenino. Analizando la composición, reglamentos y personal de la Camarería Mayor podemos concluir que, en todo caso, ese espacio muestra a las mujeres nobles alejadas de una concepción cultural pasiva y estática.

PALABRAS ClAVE: siglo XIX; corte; monarquía; nobleza; poder informal; capital simbólico.

The Camarería Mayor at the court of Ferdinand VII: a noble space of informal power and symbolic capital

ABSTRACT: The aim of this paper is to ascertain whether one section of the Royal Household was a space of informal power and symbolic capital for

* Este artículo se inscribe dentro del Proyecto de Investigación HAR2015-67753-P, titulado «Nobles, negociantes, políticos y redes cortesanas (España, 1788-1931)», del cual forma parte el autor. AGP (Archivo General de Palacio, Madrid), AG (Administración General), EP (Expedientes Personales); SH (Sección Histórica).

${ }^{1}$ ORCID iD: http://orcid.org/0000-0001-5124-4900.

Copyright: (C) 2020 CSIC. Este es un artículo de acceso abierto distribuido bajo los términos de una licencia de uso y distribución Creative Commons Reconocimiento 4.0 Internacional (CC-BY 4.0) 
Spanish noblewomen during Ferdinand VII's reign, which represented an intermediate period between the courtly society of the eighteenth century and the transformations brought about by liberalism as of 1833. The author seeks to begin to fill the gap in a bid, firstly to understand developments in women's situation at court, referring to documentation in the Royal Palace General Archive of Madrid, and secondly to comprehend the role attributed by the monarch to female staff. By analysing the composition, regulations and personnel of the Camareria Mayor, we can conclude that the passive and static cultural conception did not apply to Spanish noblewomen in this context.

KeY WORDS: Nineteenth Century; Court; Monarchy; Nobility; informal politics; symbolic capital.

CÓMO CITAR ESTE ARTÍCULO/CITATION: Moral Roncal, Antonio Manuel, «La Camarería Mayor en la corte de Fernando VII: Un espacio nobiliario de poder informal y capital simbólico», Hispania, 80/264 (Madrid, 2020): 139-167. https://doi.org/10.3989/hispania.2020.005.

\section{INTRODUCCIÓN}

Durante el siglo XIX, las manifestaciones y ámbitos de la política formal -instituciones, gobierno, escenario diplomático — se desarrollaron paralelamente a las propias de la política informal — grupos cortesanos, redes de poder, influencia clientelar...-, lo que ha motivado, desde hace unos años, el crecimiento de análisis historiográficos del segundo nivel, teniendo en cuenta los abundantes trabajos que, tradicionalmente, se han centrado en el primero ${ }^{2}$. La construcción de la España liberal facilitó una constante disminución de la influencia del poder informal de los grupos cortesanos, paralelamente a la transformación de la Corona hacia su nuevo papel como institución clave del sistema constitucional y encarnación de la nación ${ }^{3}$. Analizando esa misma época se han desarrollado, recientemente, notables investigaciones sobre el periodo isabelino ${ }^{4}$. Y, dentro de las mismas, emerge un espacio reservado a las mujeres de la nobleza en la Real Casa, la Camarería Mayor, donde, excluidas

2 A los clásicos estudios sobre las cortes europeas de MOZZARELLI y OLMI, 1983, MANSEL, 1987; 1991 y LEVER, 1993, cabe unir los de VÁZQUEZ GESTAL, 2005, VESTEEGEN, 2015 y VIAL, 2016. Para el caso de España a comienzos del siglo XIX, las investigaciones de MORAL RONCAL, 2005 y SÁNCHEZ GONZÁLEZ, 2003a; 2003b. Más cercanos son los estudios, sobre cortes europeas del siglo XIX, de TRÉTOUT, 2009. BRANDA, 2011. MAUDUIT, 2012. BOUDOUN, 2016.

3 SAN NARCISO, 2017c.

${ }^{4}$ Entre los que destacan NÚÑEZ GARCÍA, 2018. SÁNCHEZ GARCÍA, 2018a; 2018b. SAN NARCISO, 2017b. VILCHES GARCÍA, 2018. 
de la esfera pública de participación política, tuvieron acceso directo al poder procedente de la reina, a las sendas por las que transitaba y los medios adecuados para forjarlo. Por otra parte, la distinción que constituía una seña de identidad de la nobleza podía alimentarse a través de la participación de estas mujeres en un escenario que facilitaba la acumulación de capital simbólico. En este sentido, se evidencia una laguna entre los estudios de la Casa de la Reina en el siglo XVIII y los centrados en el reinado de Isabel II $^{5}$.

\section{LOS ESPACIOS FEMENINOS DE LA CORTE}

La corte fue un lugar sexualmente diferenciado. Las mujeres ocuparon un espacio institucional propio, identificado con la Casa de la Reina en la Baja Edad Media, donde habitaban familiares, ricashembras, criadas hijas de nobles y criadas siervas o moras. La reina Isabel I de Castilla heredó esta tradición y, según sus cronistas, la desarrolló extraordinariamente ${ }^{6}$. En la Edad Moderna, como otras secciones de la Real Casa, tarde o temprano se tuvo que reglamentar el número y funciones de su personal e, indirectamente, de sus posibles influencias, ya que podía constituirse como un campo de poder informal. Así lo hicieron las etiquetas de 1575 y 1603 donde, si bien se confirmó la presencia de personal masculino, fueron solamente mujeres quienes formaron su Cámara ${ }^{7}$. La camarera mayor fue su figura central y, en su entorno, fue creciendo el personal y ganando espacios hasta llegar a su culmen bajo la regencia de Mariana de Austria. Al ser más ostensible la identificación de la Corona con el sexo femenino, acudiendo la reina más frecuentemente a actos oficiales y festivos, el número de mujeres nobles en la corte aumentó, paralelamente a su influencia en las relaciones clientelares y de poder ${ }^{8}$.

La instalación en el trono de España de los Borbones modificó sustancialmente esta situación, heredada del último Habsburgo, cuyas dos consortes no habían disminuido la visibilidad femenina en la corte. Si bien no se llevó a cabo el plan de Orry en 1705 — que hubiera eliminado la Casa de la Reina — se

5 SAN NARCISO, 2017a; 2018a; 2018b; $2018 d$.

${ }^{6}$ Cómo valora y analiza FERNÁNDEZ DE CÓRDOBA MIRALLES, 2002: 144-172.

${ }^{7}$ El primer texto de 1575 son las Ordenanzas y Etiquetas de la Casa de la reina Ana de Austria, época del servicio femenino que analiza GARCÍA PRIETO, 2018. La Real Cédula e Instrucción de Felipe III, fechada el 9 de julio de 1603, fue expedida para determinar y explicar las facultades y obligaciones de la camarera mayor. Se recordó la vigencia de ambos documentos en enero de 1786, cuando fue nombrada para ese cargo la marquesa de San Juan, viuda del marqués de Bélgida, AGP, personal, 955/7.

${ }^{8}$ Estudios imprescindibles para abordar la historia de la Casa de la Reina y su personal en esta época son los de LÓPEZ-CORDÓN, 1998; 2003; 2011; y, específicamente, sobre la figura de la camarera mayor.

Hispania, 2020, vol. LXXX, n. ${ }^{\circ}$ 264, enero-abril, págs. 139-167, ISSN: 0018-2141, e-ISSN: 1988-8368 https://doi.org/10.3989/hispania.2020.005 
impusieron novedades como la elección de una extranjera como camarera mayor, se redujo cierto número de servidoras, y se ordenó, a partir de 1712, que la reina se sirviera de damas nobles casadas, pero no necesariamente de la Grandeza, por lo que las regias consortes pudieron rodearse de extranjeras, francesas y flamencas, esposas de servidores de la Corona. Conforme fue avanzando el siglo XVIII, si bien en los puestos superiores del servicio femenino los ascensos se produjeron ordenadamente, en todas las categorías se superó el número establecido en planta, sobre todo en las camaristas. Hasta unas doscientas mujeres llegaron a formar la servidumbre de todas las componentes de la familia real. Ni el cardenal Alberoni ni el marqués de la Ensenada se atrevieron a suprimir la Casa de la Reina, pese a sus claras inclinaciones en ese sentido. Éste último se limitó a reducir su personal al ajustarlo a un relación fija de puestos, estableciendo unas partidas presupuestarias claras para sus sueldos y prohibiendo aumentar su número. Bien es cierto que se aceptaron supernumerarias que, si bien no cobraban nada, sumaban antigüedad para cubrir vacantes $^{9}$. A las órdenes del mayordomo mayor se situaba el personal masculino (peluqueros, maestros, zapatero...) que atendía a la reina e infantas ${ }^{10}$.

La reina Bárbara de Braganza alteró el número de personal a su gusto, así como la reina María Amalia de Sajonia - a la que acompañó su servidumbre napolitana-, aunque ambas mantuvieran la costumbre de aceptar la planta heredada. Pero, tras el fallecimiento de la esposa de Carlos III, el reglamento de la Real Casa de 1761 incorporó definitivamente la Casa de la Reina o Camarería Mayor a la del Rey ${ }^{11}$. El personal fue reubicado lentamente en los cuartos de los infantes e infantas o, a partir de 1765, de la princesa de Asturias, y, al no existir la figura de la reina, la camarera mayor se convirtió en camarera de palacio. Con la llegada al trono de María Luisa de Parma continuaron las modificaciones habituales del número de servidoras - de acuerdo al criterio de la soberana-, disminuyendo notablemente la presencia de nobles extranjeras. La camarera mayor y numerosas damas fueron seleccionadas entre las esposas y viudas de grandes de España, por lo que la alta nobleza consideró que había recuperado su lugar natural, transigiendo con la existencia a su lado de protegidas de la reina, algunas muy alejadas de su rango, como ciertas familiares del ministro Manuel Godoy ${ }^{12}$. Todo ello demuestra que, sin romper totalmente con

9 LÓPEZ-CORDÓN, 2018b: 99-104. La reforma de Ensenada se materializó en el Reglamento General de la Casa de la Reina de 1749, AGP, AG, 939.

${ }^{10}$ Según el Reglamento de la Casa de la Reina de 1749, el personal masculino incluía un mayordomo mayor, mayordomos de semana, secretarios y una composición ciertamente parecida a la Casa del Rey en cuanto a oficios. Por Real Orden de 20 de agosto de 1766, toda la familia de mujeres de palacio debía estar subordinada a la camarera mayor, excepto la servidumbre adscrita a un criado superior en rango nombrado por el monarca, AGP, EP, 955/7.

${ }_{11}$ Reglamento General de la Real Casa (1761), AGP, AG, 939.

12 LÓPEZ CORDÓN, 2009: 1357-1398. 
los intentos de racionalización de los reglamentos, la fidelidad y la decisión regia fueron principios que se mantuvieron a la hora de nombrar el personal femenino.

En noviembre de 1808, oficialmente, la servidumbre de la reina estaba compuesta por dos camareras - la condesa de Paredes y la de Viamanuel, que lo había sido de la fallecida princesa de Asturias-, diez damas, diez señoras de honor, dos guarda mayores, cuatro azafatas, cinco dueñas y veintiún camaristas, tres de la cuales se encontraban ausentes por acompañar a la reina a Bayona y, más adelante, a su exilio. Asimismo, se contaban mozas de retrete, barrenderas, guarnicioneras, enfermeras, lavanderas, una rectora de amas, una sacristana del oratorio de damas y el personal masculino adscrito. También figuraron catorce mujeres que habían ejercido sus servicios en los cuartos de los infantes, lo que reflejó una importante reducción de este tipo de personal, el cual había sido trascendental en los últimos cuarenta años, ante la abundante prole de Carlos III y Carlos IV.

A la vuelta de su cautiverio en Francia, Fernando VII abrió un proceso de reforma de la Real Casa, tanto con el objeto de mejorar su funcionamiento como con el de eliminar cargas prolijas a la nación. Así, el 22 de mayo de 1814, ordenó la separación de la Casa Real de la administración del Estado y la centralización de poderes en su mayordomo mayor. Un mes más tarde, Fernando VII resolvió que todos sus criados gozaran de los mismos sueldos asignados antes de la Guerra de la Independencia pero, al revelarse los gastos ingentes que supondría mantener a toda la servidumbre y funcionarios que habían sobrevivido, se impuso la necesidad de recurrir a un ineludible plan de economía, al tiempo que funcionarios de la Contaduría y la Tesorería elevaban memoriales al monarca requiriendo un aumento de los ingresos para equilibrar la sección de consumos. El monarca y sus ministros comprendieron que no se podía cargar a los españoles con impuestos extraordinarios, pues la nación se encontraba en ruinas, de ahí la necesidad de eliminar lujos excesivos, ajustar los gastos a las entradas y evitar menospreciar a los criados que habían servido en la corte de Carlos IV. Así, comenzó la Tesorería regia, en el mes de junio de 1814, a adjudicarse como propios los gastos de la Casa, Cámara, Capilla, Caballerizas y Sitios Reales, que contenían tanto sueldos, pensiones y limosnas como los gastos derivados de bodas, entierros y autos, para gravar lo mínimo posible al tesoro público. Análogamente, se inició la elaboración de proyectos de reglamentos para el óptimo funcionamiento de cada una de las diversas secciones palatinas. La apertura de este proceso restaurador y renovador de la Casa y Patrimonio Real se inscribió en la común orientación centralizadora, reformista y racionalizadora que había caracterizado a esta institución en el siglo XVIII ${ }^{13}$.

${ }^{13}$ La organización de la Real Casa y Patrimonio en este reinado centra los estudios de MORAL RONCAL, 2005: 14-20; 2018: 154-160.

Hispania, 2020, vol. LXXX, n. ${ }^{\circ}$ 264, enero-abril, págs. 139-167, ISSN: 0018-2141, e-ISSN: 1988-8368 https://doi.org/10.3989/hispania.2020.005 


\section{LAS CAMARERAS MAYORES}

\section{Mujeres aristócratas en las gradas del trono}

Fernando VII heredó de su madre una importante lista de personal femenino, que dispuso bajo la dirección interina de María de la Encarnación Álvarez de Toledo y Gonzaga, marquesa de Mondéjar y condesa de Bélgida (1755-1821), hija del marqués de Villafranca y hermana del duque de Medina Sidonia. Casada con Juan de la Cruz Belvís de Moncada y Pizarro (1756-1820), puede que su nombramiento como camarera fuera fruto de su propia carrera palatina pero, indudablemente, debió influir el hecho de que su marido fuera gentilhombre, ballestero mayor y caballerizo mayor de Carlos IV y Fernando VII ${ }^{14}$.

La marquesa de Mondéjar sabía que era un puesto para el cual resultaba un requisito imprescindible ser grande de España de primera clase y gozaba de la mayor presencia en la vida cotidiana de la reina, ya que estaba presente en el tocador, vestido, comida, besamanos general y particular de jefes de palacio, secretarios de despacho y consejeros de Estado. Si el rey viudo contrajera nuevo matrimonio, la marquesa conocía que su situación mejoraría, situándola al lado de la reina en las coberturas de grandes, tomas de almohada de sus esposas y primogénitas, recibimiento de embajadores, besamanos y demás actos protocolarios. Le asistiría en la tribuna cuando hubiera funciones religiosas - como capilla pública o estación de Semana Santa - y en los paseos. En todo caso, la camarera mayor era la autoridad suprema de toda la servidumbre femenina - por debajo sólo de la reina - a la que comunicaba siempre por escrito los avisos de sus nombramientos y verbalmente las órdenes de la soberana, así como todo lo necesario para su servicio interior ${ }^{15}$. Tenía privilegios públicos ostensibles pues, además de ocupar un espacio cercano a la familia real, podía trasladarse en coche o en sillas de manos de las Reales Caballerizas, siendo acompañada y servida por un gentilhombre con honores de caballerizo

${ }^{14}$ Juan de la Cruz Belvís de Moncada y Pizarro, III marqués de Bélgida, marqués de Mondéjar, dos veces grande de primera clase. Caballerizo mayor desde el 28 de marzo de 1798, Fernando VII decidió el 11 de mayo de 1814 que continuara en su puesto con sus honores, si bien hubo de someterse a un proceso de depuración que superó positivamente el 30 de junio de 1815. Exonerado por el gobierno constitucional el 4 de agosto de 1822, su puesto pasó al marqués de Santa Cruz. Sin embargo, la Regencia le repuso el 2 de agosto de 1823. A comienzos del siguiente año, el rey le nombró montero mayor por muerte del duque de Fernán Núñez. A partir de 1825, comenzó a solicitar permisos para tomar baños en Valencia, por lo que asumió su puesto interinamente en estos casos el marqués de Sotomayor. Fue jubilado con honores el 12 de octubre de 1833, falleciendo dos años más tarde. Véase AGP, EP, 16.605/4.

15 Llegando incluso a encargarse de realizar la lista del personal de Camarería Mayor a los que la contaduría de la Real Casa debía pagar alimentos cuando se desplazaban de jornada a los Sitios Reales, Carta del duque de Montemar a la camarera mayor, 13 de septiembre de 1821, AGP, AG, 22.887/10. 
de campo. Todo ello aumentaba su prestigio y capital simbólico. Sin embargo, la distinción que le otorgaba el cargo tenía un límite público: en las esquelas de servidoras fallecidas no podía aparecer su rango ${ }^{16}$.

La posición de la camarera mayor en el damero cortesano comenzó a resituarse con motivo de las diferencias entre una aristócrata conocedora de los elementos y las prerrogativas de su cargo y un monarca que, aunque también las conocía, hizo caso omiso a sus reclamaciones y procedió a nombrar la servidumbre de mujeres sin contar con la mediación de la marquesa. La disputa no se desarrolló directamente, sino que se manifestó a través del enfrentamiento entre la camarera y el mayordomo mayor por las competencias en el nombramiento del personal, ya que antes estaban más centradas en los jefes de las diferentes secciones de la Real Casa pero, a partir del Real Decreto de 22 de mayo de 1814, se centralizaron en el mayordomo mayor.

Si bien la marquesa de Mondéjar protestó por la medida, que suponía una merma de su autoridad y poder, la respuesta del monarca fue clara. Confirmó a la camarera mayor sus tradicionales competencias de gobierno sobre la servidumbre femenina pero le arrebató la capacidad de proponerle directamente el nombre de las mujeres que creía mejor para sus oficios. Esa herramienta de influencia la tendría que compartir, a partir de entonces, con el mayordomo mayor, a quien enviaría sus propuestas, mediante informe escrito, para posteriormente ser elevadas al monarca ${ }^{17}$. No por ello mermó el número de peticiones dirigidas a la camarera mayor, como demuestra la correspondencia que recibieron ella y sus sucesoras ${ }^{18}$.

Cabe señalar que este conflicto no se desarrolló únicamente con ella, ya que las mismas tensiones se produjeron con otros jefes palatinos como el sumiller de corps. Quien ejercía este cargo, el marqués de Ariza, elevó un escrito al conde de Miranda, mayordomo mayor, donde le acusaba de haber variado los métodos tradicionales de gestión, aumentando la oficiosidad y la arbitrariedad. En tono conciliador, Miranda le respondió señalando que el rey había deseado que los servidores se comunicaran directamente con la secretaría de Mayordomía Mayor y le advirtió que el resto de jefes estaban satisfechos con el cambio, al haber advertido claramente la mejora en la comunicación interna y la pronta evacuación de los asuntos diarios ${ }^{19}$. No obstante, el mayordomo mayor fue más

${ }^{16}$ La condesa de Tilly solicitó a Mondéjar que, en la esquela de la muerte de su hija, antigua camarista, apareciese su nombre y el cargo de camarera mayor. La marquesa le contestó que podía poner su título pero no su rango, el 8 de febrero de 1815, AGP, Fernando VII, 632/1.

17 SAN NARCISO, 2018a: 11-12.

18 P. ej. Manuela Isus de Postigo suplicó plaza de camarista para sus dos hijas, 2 de noviembre de 1814; Elvira García de Castro, lo mismo, incluso con la mitad de sueldo, pues malvivían, 6 de septiembre de 1815; Jacoba Oya de Muesas, viuda de coronel, lo pide para sí misma, 12 de julio de 1815. Véase AGP, Fernando VII, 632/1.

19 AGP, Fernando VII, 199/24. 
un secretario de despacho que un secretario de Estado, ya que el rey decidió separar la administración de la Real Casa de la estatal. Por ello, no incluyó en el Consejo de Estado - restaurado en 1815- al mayordomo mayor, sino a los secretarios tradicionales de Estado. Fernando VII demostró, desde su vuelta de Francia, que deseaba tener el control total, recordando a sus servidores, cuando fue necesario, que era el «único amo» de su casa ${ }^{20}$. En definitiva, actuando como un pater familiae.

La marquesa de Mondéjar cesó a comienzos de 1816, asumiendo la dirección de la Camarería Mayor la condesa de la Puebla del Maestre, María Antonia Fernández de Córdoba y Sarmiento, casada con Francisco de Paula Fernández de Córdoba y Pacheco (1763-1824), que también tuvo una carrera palatina destacada. Comenzó, como otros muchos criados del monarca, como gentilhombre de Cámara con ejercicio, asumiendo las tareas de sumiller de corps, desde 1815, durante las ausencias y enfermedad del titular, marqués de Ariza, hasta ser nombrado en propiedad el 1 de julio de 1820. Como consecuencia de los intentos del gobierno constitucional por controlar los altos cargos palatinos, el conde fue nombrado «camarero mayor», aunque el rey le repuso en su empleo de sumiller al finalizar el Trienio Liberal, nombrándole a continuación mayordomo mayor, cargo que ejerció hasta su muerte ${ }^{21}$. La condesa concluyó su labor tres años después de su elección, al fallecer el 6 de enero de 1819.

La siguiente elegida fue María Josefa de Contreras y Vargas (1765-1826), condesa de Alcudia y viuda de Cerralbo, cuya hermana Ana María había sido dama de la reina ${ }^{22}$. Además, su hijo mayor había sido el encargado diplomático de traer, desde Sajonia hasta Madrid, a la reina María Josefa Amalia. Por motivos de salud, la condesa de Alcudia presentó la dimisión al rey el 6 de octubre de 1823, nombrando en su lugar a la marquesa viuda de Bedmar y Escalona, Rosa María de Carvajal Manrique de Lara (1765-1840), la cual también había sido dama de la infanta María Francisca y de la reina Amalia. Su fidelidad a los monarcas fue probada durante el viaje a Sevilla y Cádiz, ejerciendo el cargo hasta el final del reinado ${ }^{23}$.Hija de un gentilhombre de cámara con ejercicio, su hermano era el duque de San Carlos, mayordomo mayor e íntimo de Fernando VII. La condesa de Alcudia se había señalado, durante el Trienio Liberal, como una integrante más del grupo de constitucionales moderados que había rodeado a la reina ${ }^{24}$. Además, tres de sus hijos se habían decantado abiertamente por el

20 MENÉNDEZ REXACH, 1987: 55-121.

21 El conde de la Puebla del Maestre falleció el 25 de marzo de 1824, AGP, EP, 854/13. Caballero del Toisón de Oro desde el 9 de octubre de 1816.

22 AGP, EP, 16.787/3. Su esposo había sido Manuel Isidoro Aguilera Galarza (1741-1802), con el cual había tenido doce hijos e hijas. Nombramiento de la camarera en AGP, EP, 26/19.

23 En 1799 contrajo matrimonio con Antonio María de Acuña Prado (1766-1810), grande de España, con el que no tuvo descendencia.

24 SAN NARCISO, 2018a: 15.

Hispania, 2020, vol. LXXX, n. ${ }^{\circ} 264$, enero-abril, págs. 139-167, ISSN: 0018-2141, e-ISSN: 1988-8368 
liberalismo: el primogénito por la rama más moderada y los pequeños, por la exaltada, de tal manera que todos tuvieron que exiliarse por motivos políticos. Quizá por ello, en Madrid, anunció públicamente su intención de ceder sus rentas gaditanas - 50.000 ducados anuales - como donativo a los monarcas, una vez que fueran redimidos del gobierno libera ${ }^{25}$. En todo caso, Fernando VII no le negó la pensión a la que tenía derecho. Su sustituta, la marquesa viuda de Bedmar, demostraría su compromiso antiliberal hasta ser defenestrada por supuestas simpatías hacia el carlismo ${ }^{26}$.

Cabe subrayar el hecho de que ninguna de las tres esposas de Fernando VII eligió a su camarera mayor, siendo exclusiva decisión del monarca. Todas las reinas se encontraron a su llegada a Madrid con que su esposo había designado a aquella que debía instruirlas en el ceremonial, costumbres y etiqueta de la corte española, así como en los personajes más notorios. El rey, si bien rompió la costumbre habitual de elegir viudas como camareras, volvió a recuperarla en los dos últimos nombramientos. Y es que el servicio a la reina hacía muy difícil compatibilizar las obligaciones del cargo con las del matrimonio, salvo que el marido fuera también un alto cargo palatino, como fue el caso de Mondéjar y Puebla.

\section{Poder formal e informal de las camareras mayores}

Aún se conservan, en el Archivo del Palacio Real, legajos que reúnen la correspondencia de la camarera mayor, a través de la cual se puede analizar la capacidad y límites del poder de estas mujeres de la alta nobleza. En ellos queda claro que la camarera mayor tenía - legalmente - la capacidad de elevar al rey, en persona, memoriales de mujeres que habían servido en la Real Casa, disponían de alguna pensión o trabajaban todavía con sueldo. Incluso las mozas de retrete podían dirigirse al monarca a través de ella, lo que aumentaba su autoridad y perpetuaba la distinción de la nobleza ${ }^{27}$. Aquellas que no reunían estas condiciones eran despachadas inmediatamente recordándoles que no era atribución de la camarera mayor presentar súplicas de nadie, recomendando —en

${ }^{25}$ La condesa de Alcudia no acompañó a los reyes a Sevilla y Cádiz, como se desprende del anuncio de sus intenciones el 24 de junio de 1823, el cual fue publicado en la Gaceta de Madrid, el 5 de julio: 111. Tuvo que ir al puerto de Santa María con la Regencia y el duque de Angulema, donde presentó su renuncia, AGP, EP, 26/19.

${ }^{26}$ El 15 de septiembre de 1834, por orden de la reina gobernadora, la marquesa viuda de Bedmar remitió al mayordomo mayor la lista de damas y señoras de honor, con sus direcciones, como parte de la depuración de carlistas de la servidumbre palatina. Como consecuencia, la marquesa de Bedmar fue separada sin sueldo el 3 de diciembre siguiente, siendo reemplazada por la marquesa de Santa Cruz. Véase AGP, EP, 16.601/15.

27 Caso de María Angela Robillard, desde Granada, 20 de septiembre de 1815, antigua moza de retrete de la reina madre que solicitaba la superior mediación de la camarera para que su marido fuera repuesto como tomador de rentas de aquella ciudad, AGP, EP, 16.601/15. 
algunos casos - que las elevaran a aquellos organismos competentes en la temática de la petición, como consejos o secretarías de despacho ${ }^{28}$. No obstante, en varias ocasiones, se respondió con más suavidad, como ante la petición de limosnas o ayudas para conventos femeninos, para lo cual recomendaban que la elevaran directamente a Mayordomía Mayor o la Tesorería regia ${ }^{29}$. O en la especial circunstancia de las antiguas amas de leche, a pesar de no ser servidoras de planta, a las que la camarera mayor otorgó un trato especial ${ }^{30}$.

También tuvo un poder importante: ayudar a certificar la fidelidad de numerosas mujeres a Fernando VII durante su cautividad en Francia, en los años de la Guerra. Debe tenerse en cuenta que, a partir de 1814, se produjo un proceso de purificación política de todas las personas ligadas - de una u otra maneraa la Real Casa y Patrimonio, sin que nadie pudiera librarse de ella ${ }^{31}$. Aquellas que servían o tenían pensiones tuvieron que pasar ese proceso. Sin embargo, la camarera mayor no mantuvo ese poder en las depuraciones de realistas que intentó realizar el gobierno constitucional durante el Trienio Liberal, ni en las decretadas en 1823 y 1834 contra liberales y carlistas, respectivamente.

En todo caso, las camareras mayores se convirtieron en un importante filtro o trampolín para las aspiraciones de mujeres que, debido a múltiples circunstancias, solicitaban y rogaban por ellas, sus esposos, hijos o familiares al monarca. A partir de las disposiciones que aumentaron la autoridad del mayordomo mayor, la camarera mayor tuvo que elevar a Fernando VII memoriales a través de esa figura masculina. Sin embargo, como despachaba con el rey, también logró - como narró a sus demandantes - colocar en sus manos algunos de ellos. Pero su resolución le estuvo vedada, como así reconoció la marquesa de Mondéjar en carta a una antigua camarista: «En mí no residen más facultades que entregar a S. M. los memoriales que las señoras me remiten, pero las resultas no puedo yo saberlas a no ser solicitud que corresponda a mi empleo ${ }^{32}$.

Cabe recordar que, sin el permiso regio, numerosas camaristas y antiguas servidoras no podían trasladarse a Madrid, si vivían en otros lugares, por lo que ese plácet — conseguido a través de la camarera mayor — resultaba imprescindible,

${ }^{28}$ AGP, Fernando VII, 632/1: Correspondencia de la camarera mayor. Petición y respuesta a Joaquina Jiménez, 22 de agosto de 1814.

${ }_{29}$ Carta de la camarera mayor a sor Orosia de San Juan Evangelista, sin fechar. Aunque algunas veces, la camarera mayor la deslizó a las manos del rey, como agradece la abadesa Josefa de la Asunción el 16 de abril de 1824, AGP, AG, 22875/10.

${ }^{30}$ Caso de Gaspara Beltrán, que solicitó al rey empleo para su yerno como tesorero de renta de salinas o contador de tabacos en Cataluña, 14 de septiembre de 1815, AGP, Fernando VII, 632/1.

${ }_{31}$ Por ello, las agraciadas con su declaración o certificaciones agradecieron a la camarera mayor su gesto, como Ramona Astrande y María Cara Milles, en carta de 19 de diciembre de 1815, AGP, Fernando VII, 632/1.

32 Respuesta a Teresa Silva, 9 de junio de 1815, AGP, Fernando VII, 632/1. 
si querían solucionar asuntos administrativos decisivos, como su pensión de viudedad, o impulsar una carrera profesional a sus familiares más cercanos ${ }^{33}$. Muchas de ellas habían contraído matrimonio con funcionarios civiles o militares que, al fallecer, les habían dejado con abundante prole y escasos recursos, por lo que intentaban sacar adelante a su familia o lograr alguna pensión que aliviara su situación. Sin olvidarse que, tras la Guerra de la Independencia, el cobro atrasado de sueldos y viudedades fue la tónica normal durante todo el reinado de Fernando VII, por lo que la Camarería Mayor recibió numerosas denuncias sobre impagos ${ }^{34}$. Igualmente, cuando debían viajar al extranjero, por asuntos personales o de salud, debían solicitar permiso al rey. En algún caso, la camarera mayor recibió petición de algún hombre que, generalmente, fue el marido de una antigua servidora, que acompañaba su petición a la que previamente le había enviado su esposa ${ }^{35}$. En todo caso, para presionar o conseguir sus favores, algunas demandantes no sólo expusieron el penoso estado de sus economías, su viudedad y sus numerosos hijos sino que, aquellas que pudieron, recordaron a la camarera mayor que era su madrina de boda, que tenían parientes eclesiásticos o lazos con los voluntarios realistas ${ }^{36}$. De esta manera, estas mujeres supieron defender bien sus intereses, encontrando resortes para sobrevivir en tiempos difíciles, rompiendo moldes culturales vigentes de pasividad y cesión tutorial a un varón.

La camarera mayor logró mantener algunos mecanismos de poder informal, pues recibió recomendaciones de damas de la nobleza - como la marquesa de Lazán o la condesa de Miranda - para puestos del organigrama cortesano femenino. Algunas aristócratas utilizaron este conducto para comunicar al rey noticias de su familia o estado, como la marquesa de San Andrés al tomar los hábitos en convento ${ }^{37}$; solicitar permiso para vestir de luto ${ }^{38}$; o rogar su permanencia en

${ }_{33}$ P. ej., Solicitud de Maria Luisa Dusmet desde Valencia, 3 de noviembre de 1814; Memorial de María de Peralta desde Granada, 2 de noviembre, necesita ir a Madrid para lograr pensión del Montepío militar, AGP, Fernando VII, 632/1.

${ }^{34}$ P. ej., María Manuela Larreta, desde Tolosa, demandaba el abono de su pensión, que no había cobrado desde hacía un año, 21 de diciembre de 1815, AGP, Fernando VII, 632/1.

${ }^{35} \mathrm{Tal}$ fue el caso de Diego Contador, antiguo gobernador político y militar de El Ferrol, casado con una antigua camarista, Teresa Silva, cartas de 11, 18 y 21 de octubre de 1814. Su esposa consiguió pensión. Sin aludir a ninguna mujer, se dirigió a la camarera el oficial del ejército josefino Joaquín Romero, que suplicó un empleo aunque fuera en América, el 9 de noviembre de 1816, desde Granada. Véase AGP, Fernando VII, 632/1.

${ }^{36}$ Multitud de casos en los legajos titulados Concesión de audiencias particulares, 1825 a 1833, AGP, AG, 22.872 y 22.873.

37 Carta de la marquesa de San Andrés a la camarera mayor, 11 de septiembre de 1814. También comunicaban traslados y viajes por enfermedades de sus maridos, para que remitieran la correspondencia, como la condesa de Quintanilla, 28 de octubre de 1815. Véase AGP, Fernando VII, 632/1.

${ }_{38}$ Así lo solicitó la condesa de Viamanuel, antigua camarera mayor, 6 de noviembre de 1815, AGP, Fernando VII, 632/1. 
el extranjero, debido a su pobreza y salud, como la condesa de Villagonzalo y la marquesa de San Felices ${ }^{39}$.

Paralelamente, la camarera mayor continuó siendo un tamiz a las peticiones de audiencia con el rey, pues él mismo lo confirmó en 1829, al ordenar que la camarera mayor siguiera cumpliendo con sus obligaciones, pese a la muerte de la reina Amalia. La marquesa viuda de Bedmar debía seguir elevando «los anuncios a S. M. de las embajadoras y demás señoras que soliciten la honra de hablarle, como igualmente en la de conceder permiso y formar las listas de las personas de su sexo que pretendan audiencia de S. M.» ${ }^{40}$.

Asimismo, tuvo un papel en la organización y ejecución de actos públicos y ceremonias palatinas, permaneciendo al lado de la reina, encargándose de recibir regalos particulares para ella. Paralelamente, se añadieron cierta serie de facultades informales derivadas de la gran intimidad, contacto físico y servicio directo con la reina, al acompañarla en todo momento. Esa capacidad de compartir los espacios y los tiempos de la soberana le confirió gran valor simbólico a este cargo, motivando la dignidad y las consideraciones especiales que se le concedieron. Si bien se especula sobre la posibilidad de que la condesa de Alcudia ejerciera un papel moderador en el pensamiento político de la reina Amalia, falta una investigación más profunda para definir mejor esa influencia ${ }^{41}$. El papel de la mayor parte de las camareras mayores sobre las consortes regias parece que fue comedido, tal vez por la rápida sucesión de las mismas, motivando que el nexo común de todas ellas fuera su lealtad a la figura de Fernando VII y su carácter discreto.

\section{COMPAGINAR SERVICIO Y ECONOMÍAS}

Como respuesta a la reorganización de posguerra, el 22 de diciembre de 1815, la camarera mayor elevó un proyecto de planta de servidoras bajo su autoridad, incluyendo los sueldos que, en aquellos momentos, estaban asignados ${ }^{42}$. Si se compara este documento con la planta elaborada por la marquesa-condesa

39 Viudas, residentes en Francia, mayores, leales a la causa del rey en la guerra. Lo solicitaron y el rey les concedió permiso. Eran tías del señor de Rubianes. Véase AGP, Fernando VII, 632/1.

${ }^{40}$ Carta de Francisco Blasco, encargado de mayordomía mayor, a la camarera mayor, 27 de mayo de 1829, AGP, AG, 22.845/7.

${ }_{41}$ Unas primeras aproximaciones son las aportaciones de LÓPEZ CORDÓN, 2015: 90. LA PARRA, 2018: 385-390.

${ }_{42}$ Plan o arreglo del número y clases de que debe constar en lo sucesivo la nueva planta de la servidumbre de señoras empleadas en el Real Palacio, con inclusión de otras personas que dependen de la Camarería mayor, y los sueldos que actualmente disfrutan para la debida inteligencia y aprobación de S. M., AGP, AG, 22.844/2. 
de Paredes, en Aranjuez el 28 de abril de 1802, pueden apreciarse continuidades y novedades. La tabla I comprende la servidumbre asignada a la reina, en la que se incluye la secretaría de la Camarería Mayor. Se puede concluir que, en general, el número oficial de empleadas se mantuvo en los límites señalados antes de la Guerra de la Independencia, aumentando en algunos casos en pequeño número, reduciéndose tan sólo el número de guarda mayores de dos a una mujer. En la época anterior a la Guerra, una se encargaba del Palacio Real de Madrid y otra, de todos los Reales Sitios. Estas servidoras eran señoras de honor que recibían directamente órdenes de la reina o de la camarera mayor para la custodia y gobierno de la Portería de Damas, avalando con su vigilancia los trabajos encomendados a las mujeres que allí vivían y a los porteros, criadas y asistentas; vigilaban estrechamente las visitas de familiares, entradas y salidas del personal ${ }^{43}$. Se encargaban de regular la presencia de espectadoras en algunas ceremonias palatinas, como el lavatorio y comida de pobres, ya que, desde 1816, la camarera mayor ordenó que sólo pudieran acceder a verla - desde las claraboyas del salón de columnas - las servidoras y sus familiares, negándose a permitir el paso a amistades de las mismas. A partir de 1828, la reina María Josefa Amalia ordenó que los porteros de damas expusieran y organizaran el parte diario de salidas y entradas del personal femenino, como se hacía anteriormente ${ }^{44}$. La custodia y guarda de las mujeres muestra hasta qué punto el mundo social de la corte, en cada uno de los niveles de articulación, estaba ordenado de acuerdo a una tácita distinción de sexos. No se trataba, sin embargo, de una exclusión, sino de diferenciación y jerarquía.

Si en 1802 no se apuntó nada sobre la servidumbre masculina en la secretaría de la Camarería Mayor, Mondéjar defendió la presencia de un secretario, que debía ser gentilhombre o parecido, en obligaciones y consideración, a los secretarios de Sumillería y Caballerizas. Con este gesto, la camarera mayor demostraba su voluntad de rodearse de un personal semejante al de otros jefes y secciones de la Real Casa. Precisamente, utilizó este mismo argumento para justificar la presencia de un oficial en su secretaría, pues todo ello redundaba indirectamente en una mayor posición - y reconocimiento de la misma- en el damero cortesano, lo cual consiguió. La servidumbre masculina bajo su mando se ciñó a los citados, a los que añadió los porteros y ayudantes de la Real Portería de Damas, pues el resto del servicio de hombres de las mujeres de la familia real permaneció bajo la jurisdicción del mayordomo mayor y del sumiller de corps ${ }^{45}$.

\footnotetext{
43 AGP, AG, 22.868/ 17 y 22.884/1.

${ }^{44}$ Carta de la camarera mayor a la guarda mayor, 19 de octubre de 1828, AGP, AG, $22.884 / 1$.

${ }^{45}$ Los reglamentos utilizados para la Real Portería de Damas y atribuciones de la guardamayor de palacio continuaron la norma de 1 de enero de 1803. La servidumbre masculina de la reina, por ejemplo, reunía un mayordomo mayor, un caballerizo mayor, un primer caballerizo y 29 criados de distintas categorías, AGP, AG, 22.871/2 y 22.884/1 y 2.
} 
Tabla I. Planta de la Camarería Mayor. Servidumbre de la reina

\begin{tabular}{|l|c|c|c|c|c|}
\hline \multicolumn{1}{|c|}{ Clases } & $\begin{array}{c}\text { Planta } \\
\mathbf{1 8 0 2}\end{array}$ & $\begin{array}{c}\text { Planta } \\
\mathbf{1 8 1 5}\end{array}$ & $\begin{array}{c}\text { Sueldo } \\
\text { individual } \\
\mathbf{1 8 0 2}\end{array}$ & $\begin{array}{c}\text { Sueldo } \\
\text { individual } \\
\mathbf{1 8 1 5}\end{array}$ & $\begin{array}{c}\text { Reforma } \\
\text { de 1820 }\end{array}$ \\
\hline Camarera Mayor & 1 & 1 & 55.000 & 55.000 & 1 \\
\hline Damas de la reina & 8 & 8 & 50.000 & 50.000 & 6 \\
\hline Señoras de Honor & 8 & 8 & 12.000 & 12.000 & 6 \\
\hline Guardas Mayores & 2 & 1 & 22.000 & 24.000 & - \\
\hline Camaristas & Sin fijar & 12 & 9.000 & 9.000 & 8 \\
\hline Azafatas & 2 ó 3 & 5 & 11.000 & 11.000 & 4 \\
\hline Dueñas & 4 ó 5 & 5 & - & 9.000 & 4 \\
\hline Mozas de retrete & 4 ó 5 & 6 & 4.000 & 4.000 & 4 \\
\hline Barrenderas & 2 ó 3 & 6 & 3.000 & 3.000 & 4 \\
\hline Guarnecedora & 1 & 1 & 4.000 & 13.668 & 1 \\
\hline Enfermera & 1 & 2 & 3.285 & 4.000 & 2 \\
\hline Cocinera de regalo & 1 & 1 & 2.920 & 12.000 & - \\
\hline Ayudante de cocina & 1 & - & - & - & - \\
\hline Costurera & 1 & 1 & 15.000 & 5.000 & - \\
\hline Lavandera y planchadora & 1 & 2 & 12.000 & 4.000 & - \\
\hline Secretario de Camarería & - & 1 & - & 10.000 & - \\
\hline Oficial de Camarería & - & 1 & - & 5.000 & - \\
\hline Portero de Camarería & - & 1 & - & 3.300 & - \\
\hline Porteros de Damas & 9 & 6 & 5.000 & 6.600 & - \\
\hline Ayudantes de porteros & 9 & 6 & 4.000 & 5.500 & - \\
\hline Sacristana del oratorio de damas & - & 1 & - & 3.300 & 1 \\
\hline Rectora de amas & - & 1 & - & 5.500 & 1 \\
\hline Peluquero de la reina & - & 1 & - & - & - \\
\hline Total & 56 ó 60 & 78 & - & - & 42 \\
\hline
\end{tabular}

Fuente: AGP, AG, 22.844/2 y 22.868/17. El sueldo anual estaba calculado en reales de vellón. 
La marquesa de Mondéjar señaló en la plantilla la servidumbre que debería tener una princesa de Asturias, las infantas casadas y las solteras que, en este último caso, se asemejaban a las que se adjudicaban a los infantes menores de edad hasta que se les asignaba una servidumbre masculina. En la planta propuesta en 1802, tan sólo se explicitó la servidumbre de la esposa del heredero, compuesta por 12 mujeres, mientras que en 1815 se propuso elevarla hasta 24, manteniendo la idea de la marquesa-condesa de Paredes de que sus sueldos fueran iguales a los acordados para el servicio de la reina, que su camarera fuera grande de España, pero sin autoridad en la Portería de Damas ni palacio, tan sólo en el cuarto de la princesa de Asturias ${ }^{46}$. Como novedad, Mondéjar propuso una servidumbre de 18 mujeres para servir a las infantas casadas, mientras que Paredes no había señalado nada en este caso, tan sólo si estuvieran solteras se les adjudicaría un servicio de 7 mujeres. En 1815, este último grupo ascendió a 12, manteniendo la idea de su antecesora de que, para su dirección, se nombrara, no una camarera, sino un aya de la clase de grandes de España, encargada de «la enseñanza y buena instrucción de costumbres de S. A. así en lo espiritual como en lo político» ${ }^{47}$, responsable igualmente de las cuestiones de etiqueta y buen gobierno de su cuarto. Como se aprecia, una grande aseguraba a su clase, la alta nobleza, el monopolio de los escasos altos cargos femeninos en la corte.

Si bien la marquesa de Mondéjar cesó en su cargo a comienzos de 1816, su propuesta de planta fue aceptada por el rey. Con motivo de la boda de su hermano, el infante Carlos, con la infanta María Francisca de Braganza ese mismo año, se organizó la servidumbre de mujeres de la misma ateniendo al plan de Mondéjar. Se nombró como camarera mayor de la infanta a la marquesa viuda de Castromonte, que tuvo autoridad sobre las 14 mujeres asignadas al servicio de la cuñada de Fernando VII. Si no fueron 17 se debió a que se eliminó una moza de retrete y las dos señoras de honor ${ }^{48}$. Tres años más tarde, con motivo del enlace del infante Francisco de Paula — hermano menor del monarca - con

${ }^{46}$ Las categorías del servicio femenino en los cuartos de las infantas e infantes eran exactamente iguales a las de la reina; tan sólo, en caso de atender durante la infancia a los hijos e hijas de los reyes, aparecían a su lado los cargos de aya y tenienta de aya.

47 AGP, AG, 22.868/17. Los sueldos de toda la servidumbre de mujeres fueron iguales, independientemente de la persona real para la que trabajaban. Paralelamente, el proyecto de planta organizaba una posible carrera del personal: para ser guarda mayor se debía haber sido antes señora de honor; el portero de secretaría de Camarería Mayor sería considerado supernumerario de la Portería de Damas, para poder ser ascendido allí si lo merecía. Podría haber damas, señoras de honor y camaristas supernumerarias que pedirían su ascenso a titular en caso de vacante por antigüedad en sus nombramientos.

${ }_{48}$ Además, se nombró una servidumbre de 19 hombres para el cuarto de la infanta, elegida por don Carlos de la propia y aprobada finalmente por el rey, AGP, expedientes personales, 535/19. La actuación de estos infantes en la corte de Fernando VII ha sido analizada meticulosamente por MORAL RONCAL, 1999: 118-248. 
la princesa Luisa Carlota de Nápoles, la camarera mayor elevó el número de servidoras hasta la cifra de 18 mujeres, rompiendo la planta de 1815 . Su propuesta, revisada por el mayordomo mayor, fue aprobada por el rey que propuso que la camarera mayor de Luisa Carlota fuera también la marquesa de Castromonte, aunque finalmente fue nombrada la marquesa viuda de la Puebla de los Infantes ${ }^{49}$.

El 12 de enero de 1820, el rey ordenó que la Junta Gubernativa de la Real Casa examinara y propusiera un plan general de reformas, «conciliando el real servicio con la economía indispensable ${ }^{50}$. Los gastos generales superaban claramente los ingresos y las rentas de los Sitios Reales no cubrían el déficit. Por ello, al igual que a otros jefes de palacio, el mayordomo mayor escribió a la camarera mayor solicitándole que propusiera «con la brevedad que le fuere posible todas las reformas que considere útiles y convenientes en el departamento de su cargo, sin perjuicio del decoro y necesaria servidumbre de SS.MM.» $\aleph^{51}$. La condesa de Alcudia se negó a elevar ningún plan pues, como recordó, había sido siempre decisión personal de la pareja real señalar la servidumbre femenina, por lo que se limitó a exponer el número de mujeres que ejercían sus cargos con sueldo en aquellos momentos, revelando que - en comparación con la planta diseñada en 1815 - tan sólo se excedía en el número de dos camaristas. El resto de oficios o se ajustaban al número señalado o eran claramente menores, faltando por ocupar dos puestos de damas, uno en azafatas y dueñas y cinco en mozas de retrete y barrenderas.

La vuelta al sistema constitucional aumentó la necesidad de ajustar presupuestos y reducir gastos en la Real Casa y Patrimonio, por lo que, desde la temprana fecha de 14 de marzo de ese mismo año - cinco días después de que el rey jurara la constitución - el mayordomo mayor volvió a insistir a la condesa de Alcudia para que presentara una reforma o arreglo de plazas, determinando las personas y dotaciones necesarias. Dos meses tarde llegó la respuesta de la camarera mayor donde, además de enviar una lista con el nombre de las personas que formaban por entonces la planta, sugirió una reducción del número de damas, señoras de honor, azafatas, dueñas y, sobre todo, de camaristas, tal y como se aprecia en la tabla I. En el resto, defendió el mantenimiento del personal existente, sin aludir al de su propia secretaría. Ello suponía un ahorro de 104.000 reales de vellón en sueldos, es decir de un $17,01 \%$, respecto a la cifra

49 AGP, sección administrativa, 22.871/3. Expediente de la marquesa viuda de la Puebla, AGP, AG, EP, 854/11. Desde su exilio, Carlos IV advirtió a Fernando VII que no sería bueno, para la armonía familiar y dinástica, que las cuñadas no tuvieran la misma servidumbre. Además, el rey de Nápoles se sentiría desairado si su hija no tenía el mismo servicio que otras infantas, AGP, Fernando VII, 34/1 y sección histórica, 86.

${ }^{50}$ AGP, Fernando VII, 330/1.

${ }^{51}$ El conde de Miranda a la camarera mayor de palacio, 26 de enero de 1820, AGP, AG, $22.844 / 7$.

Hispania, 2020, vol. LXXX, n. ${ }^{\circ} 264$, enero-abril, págs. 139-167, ISSN: 0018-2141, e-ISSN: 1988-8368 https://doi.org/10.3989/hispania.2020.005 
total de gastos del personal de Camarería Mayor, cifrada en 611.068 en 1815. Fernando VII aprobó finalmente la propuesta de la condesa de Alcudia, pero se negó a aplicarla inmediatamente. La nueva planta se tendría en cuenta a partir del fallecimiento de las que actualmente se hallaban sirviendo a la reina, sobre todo en la década final del reinado ${ }^{52}$. De esta manera, el monarca continuó demostrando la protección regia a mujeres de la nobleza, algunas de ellas sin grandes rentas con las que mantener su estilo de vida.

En cambio, se cumplió la orden del rey por la cual se suprimía el cargo de camareras mayores y damas de sus cuñadas, las infantas, siendo destinadas de nuevo al servicio de la reina ${ }^{53}$. En agosto de 1822 llegó a Madrid la infanta María Teresa de Braganza, conocida como la princesa de Beira, y su hijo, el infante Sebastián Gabriel, con la intención de vivir en España. Acompañada de una dama, una camarista y una moza desde Portugal, no se le concedió ninguna servidora más, salvo otra camarista al año siguiente.

Tras la caída del régimen constitucional, se mantuvo la necesidad de continuar con las economías en el personal, incluido el femenino, por lo que su número no aumentó hasta el cuarto matrimonio del rey. La camarera mayor continuó siendo el cedazo oficial de las peticiones al rey de los dependientes de la Camarería Mayor, salvo de aquella servidumbre de los cuartos de las familias de los infantes e infantas, para lo cual se ordenó que previamente se aseguraran el permiso de sus señores. A partir de 1829, Fernando VII ordenó que la camarera mayor se presentase ante sus familiares diariamente para tratar temas propios de su ámbito de actuación y, en última instancia, potenciar a una persona de confianza como informante de los cuartos de sus hermanos ${ }^{54}$. Por aquellos años, la abierta preferencia de los ultrarrealistas por el infante Carlos María Isidro - apoyado por su esposa y la princesa de Beira - motivó cierta precaución familiar por parte del monarca ${ }^{55}$. Y es que el cargo de camarera mayor fue un buen observatorio de la vida de la Real Casa, por lo que siempre el rey estuvo en comunicación con las nobles designadas para su ejercicio. Desde esta tensión familiar y política se explica también que el rey nombrara nuevas damas supernumerarias que rodearan a María Cristina en los siguientes años.

${ }^{52}$ Comunicación interna del conde de Miranda a la condesa de Alcudia, 13 de mayo de 1814, AGP, AG, 22844/7. El 24 de diciembre de 1827 se denegó sueldo a la condesa de la Puebla del Maestre aludiendo a que, desde el 13 de mayo de 1820, el rey había ordenado que sólo seis damas tuvieran sueldo, aunque en 1827 lo gozaban siete y servían nueve, AGP, EP, 854/15.

53 Orden del 9 de abril de 1820, en el expediente de la marquesa viuda de Castromonte, que pasó a servir como dama de la reina, AGP, EP, 16.780/14.

${ }^{54}$ Además, el rey confirmó que el nombramiento de los dos porteros de damas que debían desempeñar su trabajo durante las jornadas en Sitios Reales era de la camarera mayor, carta de 27 de mayo de 1829, AGP, AG, 22.845/7.

${ }^{55}$ Las tensiones políticas en el seno de la familia real se analizan minuciosamente en MORAL RONCAL, 1999: 207-227. 


\section{SERVIR PARA PER PETUAR La distinción}

Si bien solamente se concedía sueldo a ocho damas de la nobleza, fueron muchas más las que podía nombrar el rey «a su real arbitrio y voluntad» como supernumerarias. Las elegidas debían ser grandes de España o sus primogénitas y acompañaban a la reina de guardia o media guardia - por estricta antigüedad - tanto en Madrid como en todos los Sitios Reales, en sus momentos de tocador, comida, paseo y otros actos cortesanos. Pero todas ellas debían presentarse, para acompañar a la soberana, en los besamanos generales y de tribunales, coberturas y tomas de almohada de grandes, recibimientos de embajadores y en diversos actos religiosos, como capillas, procesiones y estaciones de Semana Santa, lo cual acrecentaba su autoridad social y su capital simbólico.

Por debajo de ellas se encontraban las señoras de honor, también ocho de planta, aunque su número variaba según los deseos de la reina, siendo elegidas entre las mujeres o viudas de altos oficiales del ejército y títulos de Castilla. Actuaban igual y en los mismos ámbitos cortesanos que las damas y la camarera mayor. Entre las mismas se elegían dos para el cargo de guarda mayor, que compaginaban con sus obligaciones como señoras de honor, como ya se ha hecho alusión anteriormente. Bajo su responsabilidad quedaba el control y vigilancia de la honestidad de la Portería de Damas, ya que — salvo el teniente cura y el ayuda del oratorio - ningún hombre debía pernoctar. No obstante, la última responsable de «la conservación del decoro y recogimiento que debe haber así en la Portería de Damas como en los Sitios Reales» era la camarera mayor, como le recordó el rey ${ }^{56}$. Esto muestra el cuidado por la imagen y el honor de esas mujeres, que podía llegar a afectar a la de la reina.

Algunas damas de la alta nobleza lograron un puesto honorífico en el organigrama palatino sin sueldo ni planta pero con presencia cerca de la soberana, puesto que era un signo de distinción social. En aquella sociedad, el privilegio se basaba y se reforzaba por medio de la distinción y ésta retroalimentaba, a su vez, la existencia de una nobleza cuestionada en Europa desde 1789.

El primer secretario del Despacho de Estado consultó al rey si las esposas de los Caballeros de la Orden del Toisón de Oro podían tener entrada en el tocador de la reina, gozando de igual prerrogativa que aquellas mujeres que la poseían. Fernando VII, el 26 de octubre de 1818, accedió a ello, de tal manera que podían asistir a ese acto diario de la reina junto a damas, señoras de honor y señoras de tocador. Esta última categoría se reconocía por haber ejercido sus maridos alguna jefatura palatina, fuera en el servicio civil o militar. De esta manera, de una u otra forma, la imbricación familiar del personal de la Real Casa fue muy intensa tal y como se desprende de la tabla II.

${ }^{56}$ AGP, AG, 22.845/7.

Hispania, 2020, vol. LXXX, n. ${ }^{\circ}$ 264, enero-abril, págs. 139-167, ISSN: 0018-2141, e-ISSN: 1988-8368 https://doi.org/10.3989/hispania.2020.005 
TABLA II. Servidoras de la reina y oficios palatinos de sus cónyuges (1814-1829)

\begin{tabular}{|c|c|c|c|}
\hline Señoras & Dignidad & Esposo/Hermano & Cargo palatino $^{57}$ \\
\hline $\begin{array}{l}\text { Marquesa de } \\
\text { Mondejar }\end{array}$ & $\begin{array}{l}\text { Camarera } \\
\text { Mayor }\end{array}$ & $\begin{array}{c}\text { Juan de la Cruz Belvís de } \\
\text { Moncada }\end{array}$ & $\begin{array}{c}\text { Ballestero Mayor y } \\
\text { Caballerizo Mayor del rey }\end{array}$ \\
\hline $\begin{array}{l}\text { Condesa viuda de la } \\
\text { Puebla del Maestre }\end{array}$ & $\begin{array}{l}\text { Camarera } \\
\text { Mayor }\end{array}$ & $\begin{array}{c}\text { Francisco de Paula } \\
\text { Fernández de Córdoba } \\
\text { Pacheco }\end{array}$ & $\begin{array}{l}\text { Sumiller de Corps y } \\
\text { Mayordomo Mayor }\end{array}$ \\
\hline $\begin{array}{l}\text { Marquesa viuda de } \\
\text { Bedmar }\end{array}$ & $\begin{array}{l}\text { Camarera } \\
\text { Mayor }\end{array}$ & $\begin{array}{c}\text { Su hermano es el duque } \\
\text { de San Carlos }\end{array}$ & Mayordomo Mayor \\
\hline $\begin{array}{l}\text { Condesa viuda de } \\
\text { Cheles y Viamanuel }\end{array}$ & Dama $^{58}$ & $\begin{array}{c}\text { Su hermano es el duque } \\
\text { de Castroterreño }\end{array}$ & $\begin{array}{l}\text { Capitán de R. G. } \\
\text { de Alabarderos }\end{array}$ \\
\hline $\begin{array}{l}\text { Duquesa de Arión, } \\
\text { marquesa viuda de } \\
\text { Malpica }\end{array}$ & Dama & $\begin{array}{l}\text { Manuel Fernández de } \\
\text { Córdoba Pimentel }\end{array}$ & Gentilhombre de Cámara \\
\hline $\begin{array}{l}\text { Duquesa viuda de } \\
\text { Frías y de Uceda }\end{array}$ & Dama & $\begin{array}{c}\text { Diego Fernández de } \\
\text { Velasco }\end{array}$ & $\begin{array}{l}\text { Sumiller de Corps } \\
\text { de Carlos IV }\end{array}$ \\
\hline $\begin{array}{l}\text { Marquesa viuda de } \\
\text { Astorga y condesa } \\
\text { de Altamira }\end{array}$ & Dama & $\begin{array}{l}\text { Vicente Osorio de } \\
\text { Moscoso }\end{array}$ & $\begin{array}{l}\text { Caballerizo Mayor } \\
\text { de Carlos IV }\end{array}$ \\
\hline Señora de Rubianes & Dama & $\begin{array}{l}\text { Miguel Gayoso de } \\
\text { Mendoza }\end{array}$ & Gentilhombre de Cámara \\
\hline Duquesa de Alagón & Dama & $\begin{array}{l}\text { Francisco Espés } \\
\text { Fernández de Córdoba }\end{array}$ & $\begin{array}{l}\text { Capitán de la R.G. } \\
\text { de Corps }\end{array}$ \\
\hline $\begin{array}{c}\text { Marquesa de } \\
\text { Villanueva del } \\
\text { Duero, condesa de } \\
\text { Villariezo }\end{array}$ & Dama & $\begin{array}{l}\text { Valentín Belvís de } \\
\text { Moncada }\end{array}$ & $\begin{array}{c}\text { Caballerizo Mayor } \\
\text { del infante Carlos María }\end{array}$ \\
\hline $\begin{array}{c}\text { Duquesa de San } \\
\text { Carlos }\end{array}$ & Dama & $\begin{array}{c}\text { José Miguel de Carvajal } \\
\text { Manrique de Lara }\end{array}$ & Mayordomo Mayor del rey \\
\hline $\begin{array}{c}\text { Marquesa de Gracia } \\
\text { Real }\end{array}$ & Dama & Joaquín Villena & $\begin{array}{l}\text { Mayordomo Mayor } \\
\text { de Carlos IV }\end{array}$ \\
\hline
\end{tabular}

${ }^{57}$ En los expedientes personales de sus maridos o hermanos se puede constatar que ocuparon varios en la Real Casa, pero exponemos sólo alguno de los más importantes.

${ }^{58} \mathrm{La}$ condesa viuda de Viamanuel fue dama de la reina desde el 6 de septiembre de 1792. Nombrada camarera mayor de la princesa de Asturias, la primera esposa de Fernando VII, el 5 de junio de 1802 . 


\begin{tabular}{|c|c|c|c|}
\hline Señoras & Dignidad & Esposo/Hermano & Cargo palatino \\
\hline $\begin{array}{c}\text { Marquesa viuda } \\
\text { de Mos }\end{array}$ & Dama & $\begin{array}{l}\text { Benito Correa } \\
\text { Sotomayor }\end{array}$ & $\begin{array}{l}\text { Mayordomo Mayor de } \\
\text { reina madre y del rey }\end{array}$ \\
\hline $\begin{array}{c}\text { Marquesa de La } \\
\text { Lapilla y } \\
\text { Monasterio }\end{array}$ & Dama & Nicolás Centurión y Vera & $\begin{array}{c}\text { Caballerizo Mayor } \\
\text { de la reina }\end{array}$ \\
\hline $\begin{array}{l}\text { Marquesa de } \\
\text { Castelar }\end{array}$ & Dama & $\begin{array}{c}\text { Ramón Patiño Pérez } \\
\text { Osorio }\end{array}$ & $\begin{array}{l}\text { Capitán de R. C. } \\
\text { de Alabarderos }\end{array}$ \\
\hline $\begin{array}{l}\text { Condesa viuda de } \\
\text { Lalaing y de Buñol }\end{array}$ & Dama & Joaquín Roca Castellón & $\begin{array}{l}\text { Mayordomo Mayor } \\
\text { de la reina madre }\end{array}$ \\
\hline $\begin{array}{c}\text { Condesa de la } \\
\text { Puebla del Maestre }\end{array}$ & Dama & $\begin{array}{c}\text { Francisco de Paula } \\
\text { Fernández de Córdova }\end{array}$ & $\begin{array}{c}\text { Sus suegros fueron } \\
\text { sumiller y camarera mayor }\end{array}$ \\
\hline $\begin{array}{l}\text { Marquesa de } \\
\text { Valmediano }\end{array}$ & Dama & $\begin{array}{c}\text { Andrés Avelino de } \\
\text { Arteaga }\end{array}$ & Gentilhombre de Cámara \\
\hline $\begin{array}{l}\text { Duquesa de } \\
\text { Medinaceli }\end{array}$ & Dama & $\begin{array}{l}\text { Luis María Fernández de } \\
\text { Córdova }\end{array}$ & Gentilhombre de Cámara \\
\hline $\begin{array}{c}\text { Duquesa de } \\
\text { Villahermosa }\end{array}$ & Dama & $\begin{array}{c}\text { José Antonio de Aragón } \\
\text { Azlor }\end{array}$ & Gentilhombre de Cámara \\
\hline $\begin{array}{c}\text { Condesa de } \\
\text { Revillagigedo }\end{array}$ & Dama & $\begin{array}{c}\text { José María Fernández de } \\
\text { Córdova }\end{array}$ & Gentilhombre de Cámara \\
\hline $\begin{array}{l}\text { Duquesa viuda de } \\
\text { Osuna }\end{array}$ & $\begin{array}{l}\text { Señora de } \\
\text { Tocador }\end{array}$ & $\begin{array}{c}\text { Pedro Alcántara Tellez } \\
\text { Girón Pacheco }\end{array}$ & $\begin{array}{l}\text { Coronel de Reales } \\
\text { Guardias Españolas }\end{array}$ \\
\hline $\begin{array}{c}\text { Princesa viuda de } \\
\text { Castelfranco de } \\
\text { Sangro }\end{array}$ & $\begin{array}{l}\text { Señora de } \\
\text { Tocador }\end{array}$ & Paolo di Sangro & $\begin{array}{c}\text { Coronel de R. Guardias } \\
\text { Walonas }\end{array}$ \\
\hline Marquesa de Ariza & $\begin{array}{l}\text { Señora de } \\
\text { Tocador }\end{array}$ & $\begin{array}{l}\text { Vicente Centurión } \\
\text { Palafox }\end{array}$ & Sumiller de Corps \\
\hline Duquesa de Sedavi & $\begin{array}{l}\text { Señora de } \\
\text { Tocador }\end{array}$ & $\begin{array}{c}\text { Antonio de Barradas y } \\
\text { Baeza }\end{array}$ & Capitán de R.G. de Corps \\
\hline $\begin{array}{c}\text { Duquesa viuda de } \\
\text { Rivas }\end{array}$ & $\begin{array}{l}\text { Señora de } \\
\text { Tocador }\end{array}$ & $\begin{array}{c}\text { Juan Martín Pérez de } \\
\text { Saavedra }\end{array}$ & $\begin{array}{l}\text { Mayordomo Mayor } \\
\text { de reina madre }\end{array}$ \\
\hline $\begin{array}{c}\text { Marquesa de } \\
\text { Villafranca, } \\
\text { duquesa de Medina } \\
\text { Sidonia }\end{array}$ & $\begin{array}{l}\text { Señora de } \\
\text { Tocador }\end{array}$ & $\begin{array}{l}\text { Francisco Álvarez de } \\
\text { Toledo y Gonzaga }\end{array}$ & $\begin{array}{c}\text { Caballerizo Mayor de } \\
\text { princesa de Asturias y reina }\end{array}$ \\
\hline
\end{tabular}




\begin{tabular}{|c|c|c|c|}
\hline Señoras & Dignidad & Esposo/Hermano & Cargo palatino \\
\hline $\begin{array}{l}\text { Marquesa viuda } \\
\text { de Castelar }\end{array}$ & $\begin{array}{l}\text { Señora de } \\
\text { Tocador }\end{array}$ & $\begin{array}{l}\text { Ramón Rufino Patiño } \\
\text { Pérez Osorio }\end{array}$ & Sumiller de Corps \\
\hline $\begin{array}{c}\text { Marquesa de } \\
\text { Villadarias, } \\
\text { princesa de Santo } \\
\text { Mauro }\end{array}$ & $\begin{array}{l}\text { Señora de } \\
\text { Tocador }\end{array}$ & $\begin{array}{c}\text { Francisco Javier de } \\
\text { Santisteban y Horcasitas }\end{array}$ & $\begin{array}{l}\text { Capitán supernumerario } \\
\text { de G. de Real Persona }\end{array}$ \\
\hline $\begin{array}{l}\text { Condesa de } \\
\text { Miranda }\end{array}$ & $\begin{array}{l}\text { Señora de } \\
\text { Tocador }\end{array}$ & $\begin{array}{c}\text { Pedro Alcántara Álvarez } \\
\text { de Toledo }\end{array}$ & Mayordomo Mayor del rey \\
\hline $\begin{array}{l}\text { Marquesa } \\
\text { de Valverde }\end{array}$ & $\begin{array}{l}\text { Señora de } \\
\text { Tocador }\end{array}$ & Joaquín Samaniego & $\begin{array}{l}\text { Mayordomo Mayor } \\
\text { de la reina }\end{array}$ \\
\hline $\begin{array}{l}\text { Marquesa viuda } \\
\text { de Ayerbe }\end{array}$ & $\begin{array}{l}\text { Señora de } \\
\text { Tocador }\end{array}$ & $\begin{array}{l}\text { Pedro Jordán Urríes } \\
\text { Fuenbuena }\end{array}$ & $\begin{array}{c}\text { Mayordomo Mayor del rey } \\
\text { en Valençay }\end{array}$ \\
\hline Condesa de Fuentes & $\begin{array}{l}\text { Señora de } \\
\text { Tocador }\end{array}$ & Juan Domingo Pignateli & Capitan R.G. Walona \\
\hline $\begin{array}{c}\text { Princesa de } \\
\text { Anglona, Duquesa } \\
\text { de Osuna }\end{array}$ & $\begin{array}{l}\text { Señora de } \\
\text { Tocador }\end{array}$ & $\begin{array}{l}\text { Pedro Alcántara Téllez- } \\
\text { Girón y Pimentel, }\end{array}$ & Coronel de R.G. \\
\hline $\begin{array}{l}\text { Duquesa de Fernán } \\
\text { Núñez }\end{array}$ & $\begin{array}{l}\text { Señora de } \\
\text { Tocador }\end{array}$ & $\begin{array}{c}\text { Carlos Gutiérrez de los } \\
\text { Ríos }\end{array}$ & $\begin{array}{l}\text { Montero Mayor y } \\
\text { gentilhombre }\end{array}$ \\
\hline $\begin{array}{c}\text { Duquesa de } \\
\text { Castroterreño }\end{array}$ & $\begin{array}{l}\text { Señora de } \\
\text { Tocador }\end{array}$ & $\begin{array}{l}\text { Prudencio de } \\
\text { Guadalfajara }\end{array}$ & $\begin{array}{l}\text { Capitán de R. G. } \\
\text { de Alabarderos }\end{array}$ \\
\hline Francisca Soler & $\begin{array}{l}\text { Señora de } \\
\text { Tocador }\end{array}$ & José de Palafox y Melci & $\begin{array}{l}\text { Capitán de R.G. } \\
\text { de Alabarderos }\end{array}$ \\
\hline $\begin{array}{l}\text { Marquesa de Santa } \\
\text { Cruz }\end{array}$ & $\begin{array}{l}\text { Señora de } \\
\text { Tocador }\end{array}$ & $\begin{array}{c}\text { José Gabriel de Silva } \\
\text { Walstein }\end{array}$ & Mayordomo Mayor del rey \\
\hline $\begin{array}{l}\text { Condesa de } \\
\text { Montealegre }\end{array}$ & $\begin{array}{l}\text { Señora de } \\
\text { Tocador }\end{array}$ & $\begin{array}{c}\text { Francisco de Paula } \\
\text { Bermuy }\end{array}$ & $\begin{array}{c}\text { Capitán de G. de Real } \\
\text { Persona }\end{array}$ \\
\hline
\end{tabular}

Fuente: AGP, AG, 22.884/2. AGP, EP, 126/8,141/1, 212/20, 686/4,333/59, 1.099/19 y 20, 2.626/16, $16.505 / 4,16.605 / 4 ; 16.771 / 3,16.864 / 6$.

Fernando VII mantuvo estrictamente la antigüedad de la alta servidumbre femenina, incluso la heredada del reinado de sus padres. Así, conservó el sueldo de dama a la marquesa viuda de Branciforte, pese a ser hermana de su 
odiado Manuel Godoy ${ }^{59}$. Cabe señalar su preferencia por la lealtad demostrada por las damas que formaron parte de la servidumbre de su primera esposa, María Antonia de Borbón, como la condesa viuda de Requena o la condesa de Alcudia, y por las esposas de algunos de sus servidores cuando era príncipe de Asturias, como los marqueses de Villafranca, Ariza y Valmediano, sin olvidar a la marquesa de Valverde y Torrejón, cuyo suegro fue gentilhombre de Cámara antes de la Guerra, destinado en su cuarto. De la tabla II también se deduce que el rey rodeó a sus consortes de las esposas de sus hombres de confianza, como los duques de San Carlos, Alagón y Fernán-Núñez, que demostraron su acatamiento al rey antes y después de la Guerra de la Independencia, en hechos como los sucesos de Aranjuez en 1808. Precisamente, también colaboraron en las maniobras políticas que le llevaron al trono el duque de Frías, el conde de Villariezo, el marqués de Castelar, el marqués de Astorga y conde de Altamira, cuyas esposas formaron parte de la corte. El marido de la marquesa viuda de Ayerbe fue mayordomo mayor del monarca en Valençay; María del Carmen Álvarez de Feria, marquesa de Gracia Real, no sólo fue, primeramente, esposa de un palatino sino que, en segundas nupcias, contrajo matrimonio con el diplomático Vargas Laguna, el hombre de Fernando VII en Roma, encargado de diversas misiones ante sus padres, de ahí que su esposa actuara como confidente suya al ser dama de la reina María Luisa. Y cabe señalar también el círculo de mujeres relacionadas familiarmente con el duque de San Carlos (mayordomo mayor e íntimo del rey): su esposa; su hermana, la marquesa viuda de Bedmar; y su cuñada, la marquesa de Valmediano.

Las camaristas solían ser hijas de altos oficiales del ejército, títulos de Castilla o de familias principales del reino. Hacían guardia - por la noche-y media guardia en palacio según orden estricto de antigüedad. Podían recibir visitas de familiares pero también «de personas distinguidas» ${ }^{60}$ en una habitación de la Portería de Damas, acompañadas de una dueña: ¡un pequeño espacio de poder informal? Tal vez, en cuanto que servían a la reina a la hora de vestirse, en el tocador y en la comida y, dependiendo del grado de confianza, podían hablar con ella. No obstante, su vida estaba muy controlada, al situarse cotidianamente en el círculo femenino de la consorte real, pues sólo podían salir de palacio para hacer visitas o pasear con estricta licencia de la reina y de la camarera mayor. Al ser jóvenes, muchas de ellas terminaban contrayendo matrimonio, por lo que estos servicios proporcionaban la oportunidad de conseguir un ventajoso enlace para ellas y sus familias con funcionarios o militares. Así se comprende la queja

59 Antonia Godoy y Álvarez de Feria contrajo matrimonio con el marqués de Branciforte, virrey de Nueva España entre 1794 y 1798. Dama de la reina desde 1791, gozaba de sueldo desde el siguiente año. Tras la muerte de su marido en Marsella, permaneció en Roma, cerca de Carlos IV y María Luisa, los siguientes años, AGP, AG, 22.884/2.

${ }^{60}$ AGP, AG, 22.868/17.

Hispania, 2020, vol. LXXX, n.o 264, enero-abril, págs. 139-167, ISSN: 0018-2141, e-ISSN: 1988-8368 https://doi.org/10.3989/hispania.2020.005 
de Francisca de Paula Panigo que solicitó a la camarera mayor que elevase al rey su demanda de un empleo en la auditoría de Guerra para su marido, pues no había sido agraciado con ninguno al casarse con ella, «quando mi casamiento como todas las de mi clase por haber sido este mientras la fatal ausencia de S. M. de España. En esta época hemos sacrificado la mayor parte de sus bienes en servicios al rey y de la patria ${ }^{61}$.

TABLA III. Alta y media servidumbre femenina de planta y supernumeraria de la reina

\begin{tabular}{|l|r|r|r|r|r|r|r|r|}
\hline \multicolumn{1}{|c|}{ Cargo } & $\mathbf{1 8 1 5}$ & $\begin{array}{c}\mathbf{1 8 1 8} \\
\text { Enero }\end{array}$ & $\begin{array}{c}\mathbf{1 8 1 8} \\
\text { Mayo }\end{array}$ & $\mathbf{1 8 2 4}$ & $\mathbf{1 8 3 0}$ & $\mathbf{1 8 3 1}$ & $\mathbf{1 8 3 2}$ & $\mathbf{1 8 3 3}$ \\
\hline Camarera Mayor & 1 & 1 & 1 & 1 & 1 & 1 & 1 & 1 \\
\hline Damas & 13 & 13 & 21 & 20 & 19 & - & - & 26 \\
\hline Señoras de Honor & 7 & 6 & 14 & 5 & 4 & 4 & 3 & 2 \\
\hline Camaristas & 18 & 17 & 18 & 10 & 8 & 8 & 8 & 6 \\
\hline Camaristas sin servicio & - & - & 12 & - & 8 & - & - & - \\
\hline Señora de Tocador & - & - & 21 & 13 & - & - & - & - \\
\hline Azafatas & - & - & 4 & 2 & 4 & 4 & 4 & 5 \\
\hline Azafatas sin servicio & - & - & 2 & 6 & - & - & - & - \\
\hline Dueñas & - & - & - & 8 & 4 & 4 & 4 & 3 \\
\hline
\end{tabular}

Fuente: AGP, AG, 22.884/2. AGP, EP, 854/15.

Al casarse, las camaristas debían recibir saya y pensión de los miembros de la familia real a los que habían servido, no sólo de la Tesorería del rey sino de la de los infantes ${ }^{62}$. No resultaba menor el privilegio de casarse —una vez

${ }^{61}$ Carta a la camarera mayor, Valencia, 26 de septiembre de 1815, AGP, Fernando VII, 632/1.

62 Esto generaba un compromiso económico importante, de tal manera que el infante Francisco de Paula solicitó al rey una reforma de este privilegio de las camaristas, para evitar sus matrimonios prematuros, el 10 de diciembre de 1819. Por ello solicitó incluir en el Montepío de la Real Casa a las azafatas, camaristas y dueñas bajo una serie de reglas. Entre ellas, clarificar el grado de los militares y empleados cuyas hijas presentaban para ocupar esos puestos; fijar edad mínima de dieciocho años para camaristas y hasta cincuenta años en el caso de azafatas y dueñas; servir, al menos, seis años las camaristas para poder obtener la pensión del Montepío si se casaban; en virtud de la edad de jubilación se calcularía la parte de su sueldo para el abono de la jubilación. El fiscal general argumentó en su informe que la propuesta alteraría gravemente el reglamento del Montepío, establecido para el socorro de viudas y huérfanos. La Junta de Gobierno de la Real Casa apoyó el dictamen del fiscal y el rey hizo lo mismo, 
conseguido el permiso regio - en el cuarto de la camarera mayor, siendo madrina una de las damas, en nombre de la reina. Acto protocolario, con capital simbólico sustancial, que también se practicaba si la camarista ingresaba en una orden religosa. Muchas enlazaron con miembros de la nobleza que servían en palacio, como Manuela Cubels, que contrajo matrimonio con el conde de Negri, gentilhombre de Cámara ${ }^{63}$.

Debajo de ellas se encontraban las azafatas que eran, generalmente, viudas de militares condecorados, de hombres de letras o de políticos, que también servían de día y de noche; las dueñas eran viudas de la misma clase que las azafatas, pero hacían su guardia o media guardia en la sala de damas para avisar a la camarera mayor o al personal femenino de cualquier asunto propio del servicio.

Las tareas de la servidumbre se reglamentaron de tal manera que toda alteración provocaba sendas protestas, como la ocurrida en el verano de 1819, que fue comunicada por el infante Carlos al rey en carta:

Las camaristas, azafatas y dueñas del cuarto de Luisa se han quejado a María Francisca, indicando que lo elevarían al rey. Ella les ha dicho que esperasen para no armar revuelo. El asunto es que Francisco Antonio hace almorzar con Luisa a la marquesa de Puebla y a las damas, haciéndolas servir a las camaristas. Éstas le han representado a Francisco Antonio y, sin embargo, lo ha vuelto a hacer esta mañana y por eso han venido esta noche a decirlo. Las camaristas se quejan con mucho fundamento pues no son criadas de las camareras y de las damas. Yo pensaba haber cortado esta bagatela que no merece la pena, diciéndole a Francisco Antonio que no hacía bien en convidar a almorzar con Luisa a nadie (...), pero he pensado no decirle nada y decírtelo a ti y tú harás o me dirás que haga lo que quieras; también dice que la de Puebla las trata mal ${ }^{64}$.

El asunto fue solucionado al comunicarlo al infante Francisco de Paula, pero demostró que las categorías de la servidumbre femenina implicaban una jerarquía que se debía respetar, pues la alta posición social de estas mujeres no mermaba por servir a la reina - perpetuaba la distinción de la nobleza- pero quedaba afectaba si eran consideradas criadas de otras señoras, por muy de alto rango que fueran ellas o sus maridos.

Finalmente, por debajo de ellas, se encontraba el último grupo de oficios que ejercieron propiamente labores de servicio doméstico, como las barrenderas, las mozas de retrete, la costurera, guarnecedora, lavandera y planchadora,

por lo cual el abono de pensiones continuó adjudicándose a las tesorerías particulares de cada infante. Véase AGP, $\mathrm{SH}, 86 / 2$.

${ }^{63}$ El conde de Negri, hijo de señora de honor, comenzó su carrera cortesana como paje del rey, continuó como alférez de reales guardias walonas y gentilhombre de Cámara destinado al cuarto de los hijos del infante Carlos, AGP, EP, 738/38.

${ }^{64}$ Carta del infante Carlos al monarca, Madrid, 14 de julio de 1819. AGP, Fernando VII, caja 27.

Hispania, 2020, vol. LXXX, n.o 264, enero-abril, págs. 139-167, ISSN: 0018-2141, e-ISSN: 1988-8368

https://doi.org/10.3989/hispania.2020.005 
la cocinera de regalo y las enfermeras, que asistían a todas las criadas, seleccionadas «entre familias honradas» ${ }^{65}$. Entre enero de 1818 y junio de 1824 , generalmente, se cumplieron las plantillas de personal acordadas, contando aparte trece personas jubiladas y un ligero aumento en algunas categorías ${ }^{66}$.

Servir en palacio suponía no sólo un sueldo sino también habitación, ya que existían cuartos en la Portería de Damas para que no sólo vivieran esas mujeres, sino también sus familiares e incluso sus criadas propias ${ }^{67}$. A ello se añadía igualmente un sobresueldo de propinas, ya que la reina — en determinadas festividades anuales como su cumpleaños - ordenaba una distribución entre el bajo personal, con el control de la guarda mayor; igualmente, se repartían propinas cuando se cubría un grande, tomaba su esposa la almohada, se nombraba camarista, azafata y dueñas, se bautizaba en el cuarto del rey, se casaba una camarista, repartía aguinaldo la camarera mayor por Navidad, etc. ${ }^{68}$. Y, al igual que la alta servidumbre, si enfermaban eran atendidas por el cuerpo facultativo de la Real Casa, la camarera mayor podía ordenar que les suministraran leche de burra de las caballerizas y entraban también en la distribución de palcos y entradas para diversos espectáculos públicos. Lógicamente, la camarera mayor concedía los palcos jerárquicamente: uno para damas y señoras de honor; otro para azafatas, camaristas y dueñas; las delanteras de cazuela y asientos para la baja servidumbre ${ }^{69}$. En definitiva, trabajar en palacio constituyó una oportunidad de mejora social para esas mujeres en tiempos adversos, de ahí las continuas demandas de esos puestos por parte de antiguas servidoras para sus familiares.

\section{A MOdo de CONCLUSIón}

Más que sus consortes, Fernando VII fue quien se encargó de seleccionar y nombrar el alto personal femenino de la Real Casa entre mujeres de la nobleza

${ }^{65}$ AGP, AG, 22.868/17. Las obligaciones de las mozas de retrete, modista y barrendera fueron impresas y distribuidas, tanto para su información como para las del resto del personal femenino, AGP, AG, 22.883/7.

${ }^{66}$ Se llegó a contabilizar trece personas más, en diferentes categorías, pero debe tenerse en cuenta que el personal fallecía, se jubilaba o contraía matrimonio, AGP, AG, 22.884/2, listas de personal.

${ }^{67}$ Así se puede comprobar en la lista de personas que viven en los cuartos de la Portería de Damas, 20 de noviembre de 1834, AGP, AG, 22.884/1.

68 AGP, AG, 22.883/6 y 8, Lista de propinas, 1821-1827. En el caso del cumpleaños de la reina se repartieron 11.520 reales de propina en 1823. Cuando se cubrió el conde de Torrejón distribuyó 1.500; cuando se tomaba la almohada, la aristócrata no sólo repartía dinero sino que daba regalos a la dueña de guardia como relojes de oro, cadenas, vestidos, plata o abanicos.

${ }^{69}$ AGP, AG, 22.883/1 y 2. 
española. Al basar su elección en la fidelidad - bajo el signo de gracia y del beneficio- potenció los vínculos personales, que reformuló como una norma de justicia distributiva. Actuó, de esta manera, como padre de familia, gobernando su Casa como un paternal administrador que repartía cargos basándose en el mérito de las mujeres o de sus maridos, mediante un lenguaje de fidelidad, servicio y amistad. Premió el apoyo nobiliario a su figura durante sus años como príncipe de Asturias, el exilio en Francia, su vuelta al trono en 1814 y, a partir de entonces, a su política personal. Siempre consultado, el rey mantuvo la última palabra en cuestiones aparentemente menores de la Camarería, resultado de su concepción de monarca como pater familiae.

$\mathrm{Si}$ alguna servidora mermaba su propio mérito, disminuía la merced real, que podía denegar una petición, gracia o, incluso, llegar a su expulsión de la corte, como en octubre de 1823. Como consecuencia de su actuación durante el régimen constitucional, fueron separadas del servicio femenino - además de la sacristana, una camarista y una moza de retrete - la marquesa viuda de Astorga, la señora de Rubianes y la marquesa de Mos, a la que se le retiró la pensión de viudedad que gozaba por su marido, antiguo criado del monarca. Fernando VII separó a sus servidoras pero se negó a que los tribunales de purificación ajenos a la corte abrieran un expediente contra ellas. Salvo durante el Trienio liberal, el rey no permitió la injerencia de ninguna institución oficial en los asuntos de su Casa, aunque tuvo que admitir la lenta merma de personal -incluso en el servicio femenino - como consecuencia de las dificultades económicas.

No quiere decir por ello que la gracia fuera incompatible con la norma, pues la reglamentación de la Camarería Mayor continuó fomentándose durante su reinado - y por ende de toda la Real Casa y Patrimonio-, conformando la carrera cortesana de las servidoras, pero sin cuestionar nunca el principio de fidelidad ni la decisión última del monarca. Una estrategia que favoreció tanto la lealtad como cierta profesionalidad, necesarias ambas para un buen servicio.

Las mujeres de la nobleza, con su servicio diario en la corte, ayudaron a mantener el prestigio y retroalimentar el capital simbólico de su clase, a través de su capacidad para compartir espacios y tiempos con la familia real, evidenciando las consideraciones exclusivas con las que se les agraciaba. No sólo rodearon la vida pública y privada de la reina, sino de las infantas, manteniendo su presencia en ceremonias incluso en el periodo 1814-1816, cuando no hubo presencia femenina en la familia real de Madrid. Todo ello les ayudó a mantener una visibilidad pública en la capital y Sitios Reales que pudo facilitarles un reducido espacio de poder informal. En este sentido, queda comprobado en este artículo el adjudicado a las camareras mayores, que despacharon diariamente con el monarca y lograron mantener ciertas herramientas para vehicular peticiones, opiniones y sugerencias de cuantiosas mujeres, no solamente del estamento 
nobiliario. Por otra parte, al favorecer el matrimonio de las camaristas con funcionarios y militares, el monarca continuó manteniendo una red y una cultura clientelar de fidelidad en el organigrama administrativo, no sólo de su Casa y Patrimonio, sino también del Estado. La disolución de esa cultura política oficial y secular sería una de las consecuencias de la construcción de la monarquía liberal durante el siglo XIX.

\section{Bibliografía}

Boudon, Jacques Olivier (dir.), La cour impériale sous le Premier et Second Empire, París, SPM, 2016.

Branda, Pierre, Napoléon et ses hommes: la Maison de l'empereur, 1804-1815, París, Fayard, 2012.

Fernández de Córdova Miralles, Álvaro, La corte de Isabel I. Ritos y ceremonias de una reina (1474-1504), Madrid, Dikynson, 2002.

García Prieto, Elisa, Una corte en femenino Servicio áulico y carrera cortesana en tiempos de Felipe II, Madrid, Marcial Pons, 2018.

La Parra, Emilio, Godoy, la aventura del poder, Barcelona, Tusquets, 2002.

La Parra, Emilio, Fernando VII, Barcelona, Tusquets, 2018.

Lever, Evelyne, Louis XVIII, París, Fayard, 1993.

López-Cordón Cortezo, María Victoria, «Mujer, poder y apariencia o las vicisitudes de una regencia», Studia Histórica. Historia Moderna, 19 (Salamanca, 1998): 49-66.

López-Cordón Cortezo, María Victoria, «Entre damas anda el juego: las camareras mayores de Palacio en la Edad Moderna», Cuadernos de Historia Moderna, Anejo II (Madrid, 2003): 123-152.

López-Cordón Cortezo, María Victoria, «La evolución de las damas entre los siglos XVII y XVIII», en José Martínez Millán y María Paula Marçal Lourenço (coords.), Las relaciones discretas entre las Monarquías Hispana y Portuguesa: Las Casas de las Reinas (siglos XV-XIX), Madrid, Ediciones Polifemo, 2009, vol. 2: 1357-1398.

López-Cordón Cortezo, María Victoria, «Servicios y favores en la Casa de la Reina», en Francisco Andújar Castillo y María del Mar Felices de la Fuente (coords.), El poder del dinero: ventas de cargos y honores en el Antiguo Régimen, Madrid, Biblioteca Nueva, 2011: 223-244.

López-Cordón Cortezo, María Victoria, «En las redes palatinas: De damas intrigantes a señoras políticas», en José Martínez Millán, Concepción Camarero Bullón y Marcelo Luzzi Traficante (coords.), La Corte de los Borbones: Crisis del modelo cortesano, Madrid, Ediciones Polifemo, 2013, vol. 2: 941-974.

López-Cordón Cortezo, María Victoria, «Entre Witina y Julia: el viaje intelectual de María Josefa Amalia de Sajonia», en María Dolores Gimeno Puyol y Ernesto Viamonte Lucientes (coords.), Los viajes de la Razón: Estudios dieciochistas en homenaje a María-Dolores Albiac Blanco, Zaragoza, Institución Fernando el Católico, 2015: 83-101. 
López-Cordón Cortezo, María Victoria, «El espejo palatino o la malla de las damas: ¿sociabilidad cortesana o cultura política?», en Manuel-Reyes García Hurtado (coord.), El siglo XVIII en femenino, Madrid, Síntesis, 2016: 79-112.

López-Cordón Cortezo, María Victoria, «Representar en listas el personal de la Casa Real Española», en Gregorio Salinero y Miguel Ángel Melón Jiménez (dirs.), Le temps des listes. Representer, savoir et croire à l'epoque moderne, Cáceres, Universidad de Extremadura, Servicio de Publicaciones, 2018a: 287-316.

López-Cordón Cortezo, María Victoria, «La corte de los Borbones en el siglo XVIII: conflictos, reglas y jerarquías», en Raquel Sánchez y David San Narciso (coords.), La cuestión de palacio. Corte y cortesanos en la España contemporánea, Granada, Comares, 2018b: 87-120.

Mansel, Philip, The eagle in splendour: Napoleon I and his court, Londres, George Philip, 1987.

Mansel, Philip, The court of France 1789-1830, Cambridge, Cambridge University Press, 1991.

Mauduit, Xavier, Le ministère du faste: la Maison de l'empereur Napoléon III, París, Fayard, 2012.

Menéndez Rexach, Ángel, «La separación entre la Casa del rey y la administración del Estado (1814-1820)», Revista de Estudios Políticos, 55 (1987): 55-121.

Moral Roncal, Antonio Manuel, Carlos V de Borbón (1788-1855), Madrid, Actas, 1999.

Moral Roncal, Antonio Manuel, ;El enemigo en palacio! Afrancesados, liberales y carlistas en la Real Casa y Patrimonio (1814-1843), Alcalá de Henares, Servicios de Publicación de la Universidad de Alcalá, 2005.

Moral Roncal, Antonio Manuel, «La Real Casa y Patrimonio en el reinado de Fernando VII (1814-1833)», en Raquel Sánchez y David San Narciso (coords.), La cuestión de palacio. Corte y cortesanos en la España contemporánea, Granada, Comares, 2018: 155-184.

Mozzarelli, Cesare y Olmi, Giuseppe (eds.), La corte nella cultura e nella storigrafia. Immagini e posizioni tra Otto e Novecento, Roma, Bulzoni Editore, 1983.

Núñez García, Víctor Manuel, «Andaluces en la corte de Isabel II. Influencias y poder político en la Nación Liberal», Aportes. Revista de Historia contemporánea, 96 (Madrid, 2018): 65-95.

Sánchez García, Raquel, «Los gentilhombres de Palacio y la política informal en torno al monarca en España (1833-1885)», Aportes. Revista de Historia contemporánea, 96 (Madrid, 2018a): 33-64.

Sánchez García, Raquel, «A la sombra del monarca. Los cargos masculinos en la corte española (1833-1885)», en Raquel Sánchez y David San Narciso (coords.), La cuestión de palacio. Corte y cortesanos en la España contemporánea, Granada, Comares, 2018b: 185-217.

Sánchez González, Dolores del Mar, «La nueva planta para la Casa Real de Fernando VII. El desconocido reglamento de 17 de noviembre de 1815», Cuadernos de Historia Moderna, Anejo II (Madrid, 2003a): 311-343.

Sánchez González, Dolores del Mar (coord.), Corte y Monarquía en España, Madrid, Centro de Estudios Ramón Areces/UNED, 2003b. 
San Narciso Martín, David, «Criadas, si bien señoras. La corte, un resorte de poder informal femenino en el siglo XIX», en Damián González, Manuel Ortíz y Juan S. Pérez Garzón, La Historia, Lost in traslation? Actas del XIII Congreso de la Asociación de Historia Contemporánea, Albacete, AHC, 2017a: 243-250.

San Narciso Martín, David, «La lucha por la privanza real. Poder, contrapoder y redes informales de influencia en la Corte de Isabel II», en Alberto Ramos Santana y Diana Repeto García (eds. lits.), Poder, contrapoder y sus representaciones: XVII Encuentro de la Ilustración al Romanticismo: España, Europa y América (17501850), Cádiz, Universidad de Cádiz, 2017b: 201-217.

San Narciso Martín, David, «Viejos ropajes para una nueva monarquía. Género y nación en la refundación simbólica de la Corona de Isabel II (1858-1866)», Ayer, 108 (Madrid, 2017c): 203-230.

San Narciso Martín, David, «Políticas desde las Cámaras de Palacio. Las Camareras Mayores en la España liberal», Aportes. Revista de Historia contemporánea, 96 (Madrid, 2018a): 9-31.

San Narciso Martín David, «Palaciegas en los bastidores de la política. Los destinos femeninos en la corte de los Borbones (1833-1885)», en Raquel Sánchez y David San Narciso (coords.), La cuestión de palacio. Corte y cortesanos en la España contemporánea, Granada, Comares, 2018b: 217-242.

Trétout, Thibaut, «Louis-Philippe et la cour», en Hélène Becquer y Bettina Frederking (dirs.), La dignité de roi, regards sur la royauté au premier XIXe siècle, Rennes, PUR, 2009: 117-136.

Vázquez Gestal, Pablo, El espacio del poder. La corte en la historiografía modernista española y europea, Valladolid, Universidad de Valladolid, 2005.

Versteegen, Gijs, Corte y Estado en la historiografía liberal. Un cambio de paradigma, Madrid, Polifemo, 2015.

Vial, Charles Éloi, Les deniers feux de la Monarchie. La cour au siécle des révolutions, 1789-1870, París, Perrin, 2016.

Vilches García, Jorge, «La imagen progresista de Isabel II y la batalla en la corte (1833-1843)», Aportes. Revista de Historia contemporánea, 96 (Madrid, 2018): 97-126.

Recibido: 28/02/2019

Aceptado: 25/07/2019 